\title{
Comparative thallus anatomy of two Parmotrema (Parmeliaceae, lichenized Ascomycetes) with reticulate maculae ${ }^{1}$
}

\author{
Suzana Bissacot Barbosa ${ }^{1,3}$ and Marcelo Pinto Marcelli ${ }^{2}$
}

Recebido em 20/10/2009. Aceito em 21/06/2010

RESUMO - (Anatomia comparada do talo de duas espécies de Parmotrema (Parmeliaceae, Ascomycota liquenizados) com máculas reticulares). Através de técnicas convencionais para estudos histológicos em microscopia de luz com auxílio de luz polarizada e microscopia eletrônica de varredura, é descrita e comparada a anatomia do talo de duas espécies de Parmotrema com máculas reticulares, antigamente gênero Rimelia: Parmotrema cetratum (Ach.) Hale e P. clavuliferum (Räsänen) Streimann. Os dados obtidos neste estudo mostram que as espécies são anatomicamente semelhantes, incluindo-se a presença de epicórtex, a anatomia do córtex superior e as características das rizinas e dos cílios. Na medula das duas espécies é possível observar a ocorrência de aglomerados de hifas em forma estrelada associados à presença de ácido salazínico medular. Este estudo indica que as características anatômicas são constantes para o grupo estudado de Parmotrema com máculas reticulares.

Palavras-chave: anatomia, máculas reticulares, Parmotrema, Rimelia

ABSTRACT - (Comparative thallus anatomy of two Parmotrema (Parmeliaceae, lichenized Ascomycota) with reticulate maculae). Using conventional techniques for structural studies under conventional microscopy, polarizing light microscopy and scanning electron microscopy this work describes and compares the thallus anatomy of two Parmotrema species with reticulate maculae, previously included in the genus Rimelia: Parmotrema cetratum (Ach.) Hale and P. clavuliferum (Räsänen) Streimann. The data showed that the species are anatomically similar, including the presence of epicortex, the upper cortex anatomy and the characteristics of rhizines and ciliae. In the medulla of the two species there are star-shaped clusters of hyphae associated with the presence of salazinic acid. This study showed that the anatomical characteristics are constant for the Parmotrema group studied.

Key words: anatomy, reticulate maculae, Parmotrema, Rimelia

\section{Introduction}

With the improvement of observation systems, by using light microscopy and transmission and scanning electron microscopy, microcharacter morphology has shown great potencial for taxonomic application in many lichen groups (Crespo et al. 2006). Studies related to the surface structure of lichens and internal organization may provide additional characters for the revision of taxonomic concepts at family and genus levels (Hale 1976).

Moreover, several molecular and phylogenetic studies performed with lichenized fungi in recent years, including genera of the family Parmeliaceae (Elix 1997, 2003; Hawksworth \& Crespo 2002; Blanco et al. 2004 a/b; Blanco et al. 2005; Divakar et al. 2006; Crespo et al. 2007), have changed the concepts of families and genera, changing their circunscriptions, but still subject to controversy in accordance with the individual views of experts in particular areas (Crespo et al. 2006).

Blanco et al. (2005), based on morphological and molecular evidence, considered that the genus Rimelia Hale \& Fletcher should be synonymized with the large genus Parmotrema Mass. These authors considered the diagnostic characteristics of these genera, such as differences in rhizines, shape of conidia, size of spores and chemistry of medullary substances, inappropriate for the recognition of monophyletic groups in lichens.

In the species traditionally included in Rimelia, the upper surface of the thallus is more or less evenly reticulatemaculate, and at maturity, regular cracks commonly develop along the maculae, reaching the depth of the algal layer, and producing the characteristic pattern of the group (Hale \& Fletcher 1990).

The aim of this work was to perform a detailed and comparative anatomical study of the thallus of two Parmotrema species with reticulate-maculate upper surface, previously included in the genus Rimelia: P. cetratum (Ach.) Hale and $P$. clavuliferum (Räsänen) Streimann.

This work is the continuation of a project started in 2003 as part of the master's dissertation of Barbosa (2004) which aimed to describe a protocol for anatomical studies in species of Parmeliaceae (Barbosa et al. 2009a). The results presented here are part of the doctoral thesis of the first author (Barbosa 2009), who studied the application of anatomical data as auxilliary for the taxonomic definition of species and genera in Parmeliaceae.

\section{Material and methods}

The material studied was obtained from samples deposited in the Eneyda Maria P. Kauffmann Fidalgo Scientific Herbarium (SP) of the Institute of Botany of Sao Paulo, according to Table 01.

Longitudinal and transverse sections were obtained from samples taken from young regions (near the margin) and developed regions (near the center of the thallus). Three blocks were prepared for each region of the thallus samples and at least four slides of each block.

For light microscope analyses, the material was prepared according to the protocol established by Barbosa et al. (2009a) for Parmeliaceae. Samples were fixed in formalin-acetic acid-alcohol 50 (FAA 50) for 48 hours (Johansen 1940), dehydrated in a graded ethanol series, and embedded in plastic resin (Leica Historesin). Serial sections (2-5 $\mu \mathrm{m}$ thick) were sectioned in both transversely and longitudinally with a steel knife on a semi-automatic rotary microtome. Some of the sections between 2 and 5

\footnotetext{
1 Universidade Estadual Paulista, Departamento de Botânica, Instituto de Biociências, Botucatu, SP, Brazil

2 Instituto de Botânica, Seção de Micologia e Liquenologia, São Paulo, SP, Brazil

3 Corresponding author: suzibissacot@yahoo.com.br
} 
Table 1. List of the Parmotrema specimens studied with their collectors, collector number and collecting place (BR: Brazil; RS: Rio Grande do Sul state; SP: São Paulo state).

\begin{tabular}{ccc}
\hline Species & Specimens & Municipality / State / Country \\
\hline P. cetratum & P. Jungbluth, A.A. Spielmann \& L.S. Canêz 861 & Itirapina/SP/BR \\
& S.B. Barbosa \& M.P. Marcelli 407 & Botucatu/SP/BR \\
P. clavuliferum & A.A. Spielmann, L.S. Canêz \& C. Trentin 683 & Herveiras $/ \mathrm{RS} / \mathrm{BR}$ \\
& A.A. Spielmann \& J. Putzke 1303 & Herveiras $/ \mathrm{RS} / \mathrm{BR}$ \\
& A.A. Spielmann \& L.S. Canêz 745 & Sinimbu/RS/BR \\
\hline
\end{tabular}

$\mu \mathrm{m}$ thick were stained with toluidine blue $0.05 \%, \mathrm{pH} 4.7$ (O'Brien et al. $1965)$, and the remaining sections were prepared the same way as above but without staining. Permanent slides were mounted in synthetic resin and were photographed under a Zeiss photomicroscope coupled with an Olympus camera, with and without polarizing filter. Measures of cells were taken with the aid of ocular reticulum.

Freehand sections taken from fresh material were sectioned with razors or a Ranvier microtome and mounted between slide and cover-slip using glycerin and were photographed under a Zeiss photomicroscope coupled with an Olympus camera, with and without polarizing filter.

For scanning electron microscopy (SEM), air-dried samples were mounted on aluminum stubs and sputter coated with $10 \mathrm{~nm}$ of gold. Observations and micrographs were made with a FEI Quanta SEM at an acceleration voltage of $20 \mathrm{kV}$.

Description of all specimens follows the protocol developed by the Group for Lichenological Studies, Institute of Botany, Sao Paulo, state of Sao Paulo, Brazil, and adapted by Barbosa (2004) for anatomical data.

\section{Results}

\section{Parmotrema cetratum (Ach.) Hale}

Phytologia 28 (4): 335. 1974

Fig. 1

EPICORTEX 0.75-2.00 $\mu \mathrm{m}$ height (Fig. 1A). UPPER CORTEX palisade prosoplectenchymatous, 3-5 (-7) cells height (17.50-37.50 $\mu \mathrm{m})$, with slightly elongated and thick-walled cells $5.00-10.00 \times 5.00-7.50 \mu \mathrm{m}$, formed by the juxtaposition of apical cells from hyphae that project from the medulla through the algal layer, and this pattern is responsible for the palisade appearance of its cells; fissures frequently responsible for the thallus reticulated pattern; maculae formed by parallel bundles of medullary hyphae with 3-5 hyphae (12.50-62.50 $\mu \mathrm{m}$ width), which can lead to fissures in the upper cortex (Fig. 1A, 1B); cilia abundant. ALGAL LAYER 2-5 cells height (10.00-37.50 $\mu \mathrm{m})$, with rounded cells (5.00-) 10.00-12.50 $\mu \mathrm{m}$ diameter, heterogeneous cell content; hyphae 2.50-5.00 $\mu \mathrm{m} \times 7.50$ $12.50 \mu \mathrm{m}$ (Fig. 1A, 1B). MEDULLA $125.00 \times 162.50$ $\mu \mathrm{m}$ thick and mainly composed of hyphae in longitudinalhorizontal arrangement; hyphae with thin and elongated cells 2.50-3.75 $\mu \mathrm{m} \times 7.50-12.50 \mu \mathrm{m}$; presence of star-shaped clusters of hyphae with incrustations of crystals, associated with hyphae leaving the medulla to form the upper cortex and nearly the site of rhizine formation (Fig. 1A, 1B, 1C). SORALIA absent. ISIDIA absent. LOWER CORTEX prosoplectenchymatous, 1-3 cells height $(10.00-25.00 \mu \mathrm{m})$, with rounded and thick-walled cells 5.00-7.50 $\mu \mathrm{m}$ diameter (Fig. 1B, 1C).; rhizines simple to irregularly ramified, corticated, $15.00-37.50 \mu \mathrm{m}$ diameter, equivalent to 6-11 agglutinated and parallel hyphae of $1.25-2.50 \mu \mathrm{m}$ diameter each (Fig. 1B, 1C)

\section{Parmotrema clavuliferum (Räsänen) Streimann}

Bibliotheca Lichenologica 22: 93. 1986.

Fig. 2

EPICORTEX $0.65-2.50 \mu \mathrm{m}$ height (Fig. 2A, 2B). UPPER CORTEX palisade prosoplectenchymatous, 2-5 cells height $(12.50-25.00 \mu \mathrm{m})$, with slightly elongated and thick-walled 5.00-10.00 × 2.50-5.00 (-7.50) $\mu \mathrm{m}$, formed by the juxtaposition of apical cells from hyphae that project from the medulla through the algal layer, and this pattern is responsible for the palisade appearance of its cells; fissures frequently responsible for the thallus reticulated pattern; maculae formed by parallel bundles of medullary hyphae with 3-6 hyphae (10.00-50.00 $\mu \mathrm{m}$ width), that can lead to fissures in the upper cortex (Fig. 2A, 2B); cilia frequent at the margin of non sorediated lobes. ALGAL LAYER $1-4$ cells height $(5.00-17.50 \mu \mathrm{m})$, with small rounded cells $3.75-5.00(-7.50) \mu \mathrm{m}$ diameter, heterogeneous cell content; hyphae 2.50-3.75 $\mu \mathrm{m} \times 7.50$ $12.50 \mu \mathrm{m}$ (Fig. 2A, 2B). MEDULLA 50.00-75.00 $\mu \mathrm{m}$ thick and composed of hyphae in transversal-horizontal arrangement in upper and lower part of medulla; in the median region of the medulla occur mainly longitudinalhorizontal hyphae; hyphae with thin and elongated cells 2.50-3.75 $\mu \mathrm{m} \times 10.00-15.00 \mu \mathrm{m}$ (Fig. 2A, 2B); presence of star-shaped clusters of hyphae with incrustations of crystals, associated with hyphae leaving the medulla to form the upper cortex and nearly the site of rhizine formation (Fig. 2D) SORALIA 1.00-1.50 cm width, formed in the lacinulae apex; soredia rounded with 3-8 algal cells, 12.50-37.50 $\mu \mathrm{m}$ diameter, frequently corticated (Fig. 2E, 2F).; ISIDIA absent. LOWER CORTEX prosoplectenchymatous, 1-3 cells height $(7.50-17.50 \mu \mathrm{m})$, with rounded and thick-walled cells 5.00-7.50 $\mu \mathrm{m}$ diameter (Fig. 2A, 2C); rhizines simple to irregularly ramified, corticated, (25.00-) 37.50-50.00 $(-62.50) \mu \mathrm{m}$ diameter, equivalent to $10-15$ agglutinated and parallel hyphae of 2.50-3.75 diameter each (Fig. 2C).

The main anatomical characteristics of the thallus of the studied species are given in Table 2 . 


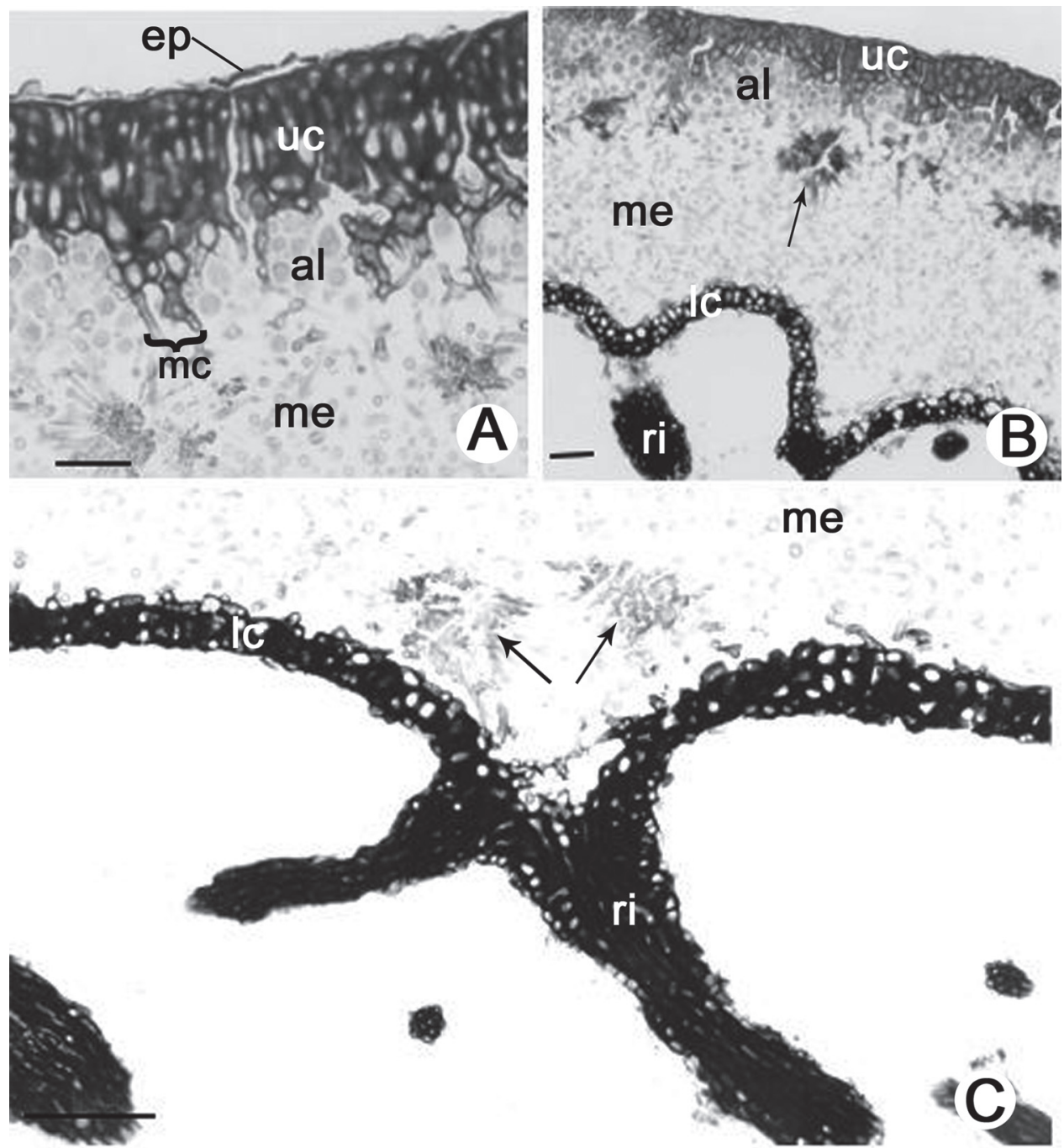

Figure 1. Thallus anatomy of Parmotrema cetratum (Ach.) Hale. (A). Detail of the upper region of the thallus indicating the epicortex (ep), upper cortex (uc), algal layer (al), maculae (mc) and part of the medulla (me). (B). Transverse section indicating the upper cortex (uc), algal layer (al), medulla (me) with lichen acid crystals (arrow), lower cortex (lc) and rhizine (ri). (C). Detail of the lower region of the thallus indicating part of the medulla (me) with crystals of lichen acid (arrows) next to rhizine (ri) and lower cortex (lc). Bars $=100 \mu \mathrm{m}(\mathrm{B}), 50 \mu \mathrm{m}(\mathrm{A}, \mathrm{C})$.

Table 2. Main anatomical features of Parmotrema cetratum (Ach.) Hale and Parmotrema clavuliferum (Räsänen) Streimann

\begin{tabular}{|c|c|c|}
\hline & P. cetratum & P. clavuliferum \\
\hline Epicortex & $0,75-2,00 \mu \mathrm{m}$ high & $0,65-2,50 \mu \mathrm{m}$ high \\
\hline Upper cortex & $\begin{array}{l}\text { palisade prosoplectenchymatous, } 3-5(-7) \text { cells high }(17,50-37,50 \mu \mathrm{m}) \text {, } \\
\text { fissures frequents }\end{array}$ & $\begin{array}{l}\text { palisade prosoplectenchymatous, } 2-5 \text { cells high }(12,50-25,00 \mu \mathrm{m}) \text {, } \\
\text { fissures frequents }\end{array}$ \\
\hline Algal layer & $2-5$ cells high $(10,00-37,50 \mu \mathrm{m})$ & $1-4$ cells high $(5,00-17,50 \mu \mathrm{m})$ \\
\hline Maculae & $\begin{array}{l}3-5 \text { hyphae }(12,50-62,50 \mu \mathrm{m} \text { width }) \text {, which can lead to fissures in the } \\
\text { upper cortex }\end{array}$ & $\begin{array}{l}\text { 3-6 hyphae }(10,00-50,00 \mu \mathrm{m} \text { width), which can lead fissures in the } \\
\text { upper cortex }\end{array}$ \\
\hline Medulla & $\begin{array}{l}125,00-162,50 \mu \mathrm{m} \text { thick and mainly composed of hyphae in } \\
\text { longitudinal-horizontal arrangement }\end{array}$ & $\begin{array}{l}50,00 \times 75,00 \mu \mathrm{m} \text { thick and composed of hyphae in transversal-horizontal } \\
\text { arrangement in upper and lower part of medulla; in the median region of } \\
\text { medulla occur mainly longitudinal-horizontal hyphae }\end{array}$ \\
\hline Crystals & presence of star-shaped clusters of hyphae with incrustations of crystals & presence of star-shaped clusters of hyphae with incrustations of crystals \\
\hline Soralia & absent & $\begin{array}{l}1000,00-1500,00 \mu \mathrm{m} \text { wideth, formed in the lacinulae apex; rounded soredia } \\
\text { with } 3-8 \text { algal cells, } 12,50-37,50 \mu \mathrm{m} \text { diameter, frequently corticated }\end{array}$ \\
\hline Lower cortex & prosoplectenchymatous, $1-3$ cells high $(10,00-25,00 \mu \mathrm{m})$ & prosoplectenchymatous, $1-3$ cells high $(7,50-17,50 \mu \mathrm{m})$ \\
\hline Rhizines & corticated, simple to irregularly ramified, $15,00-37,50 \mu \mathrm{m}$ diameter & $\begin{array}{l}\text { corticated, simple to irregularly ramified, }(25,00-) 37,50-50,00(-62,50) \\
\mu \mathrm{m} \text { diameter }\end{array}$ \\
\hline
\end{tabular}




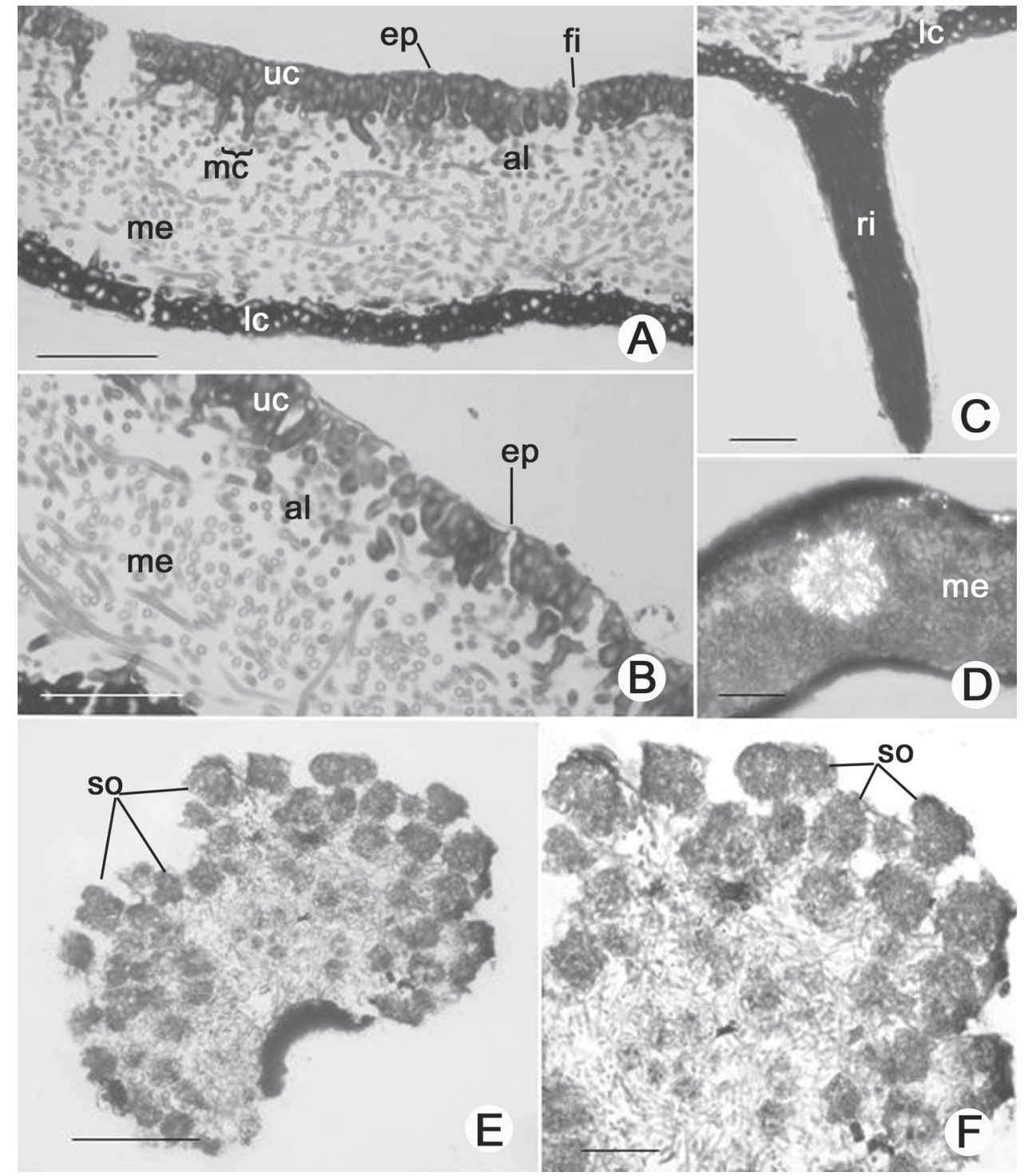

Figure 2. Thallus anatomy of Parmotrema clavuliferum (Räsänen) Streimann. (A). Transverse section showing epicortex (ep), upper cortex (ep), fissure (fi), maculae $(\mathrm{mc})$, algal layer (al), medulla (me) and lower cortex (lc). (B). Detail of the upper region of the thallus indicating the epicortex (ep), upper cortex (uc), algal layer (al) and medulla (me). (C). Detail of rhizine (ri) and lower cortex (lc). (D). Detail visualized under polarizing light showing medulla (me) with star-shaped hyphal agglomerate and crystal (cr). (E-F) Detail of soralia, showing soredia (so). Bars $=50 \mu \mathrm{m}$ (A-C, E-F), $100 \mu \mathrm{m}$ (D).

Crystal description (Fig. 3-5) - The examination of freehand sections of fresh material (Fig. 3A, 3B) revealed numerous crystals on the surface of the fungal cells in different parts of the lichen thallus, especially in the upper cortex and medulla. The crystals could be observed by using polarized light (Fig. 3A) on all surfaces of the fungal cell walls and were not restricted to adjacent regions of the sites of contact between hyphae and photobionts. The examination of nonstained sections without the aid of a polarizer (Fig. 3B) revealed the presence of star-shaped hyphal agglomerates distributed throughout the medulla, particularly in the upper region immediately below the algal layer.

From $2-5 \mu \mathrm{m}$ sections of material fixed and embedded in resin (Fig. 4A, 4B), the presence, location and characteristics of crystals could be observed in detail. Crystals concentrated in the medulla appeared as star-shaped hyphal agglomerates, $10.0-50.0 \mu \mathrm{m}$ diameter with many long, generally pointed rays irradiating from an amorphous nucleus. The rays were simple or variably branched, $1.75-2.50 \mu \mathrm{m}$ in diameter, with most located in the upper part of the medulla in the region of contact with the algal layer, forming a distinct stratum comprising a row of crystals. The apex of the rays is commonly associated with hyphae that grow from the medulla through the algal layer to form the upper cortex (Fig. 4A); however, some small, isolated groups of crystals were present in the lower medulla adjacent to the lower cortex, and directly related to sites of rhizine formation (Fig. 1C).

SEM analysis (Fig. 5A, 5B) confirmed the presence of starshaped hyphal agglomerates immediately below the algal layer and showed the crystals deposited on the surface of these hyphae. 


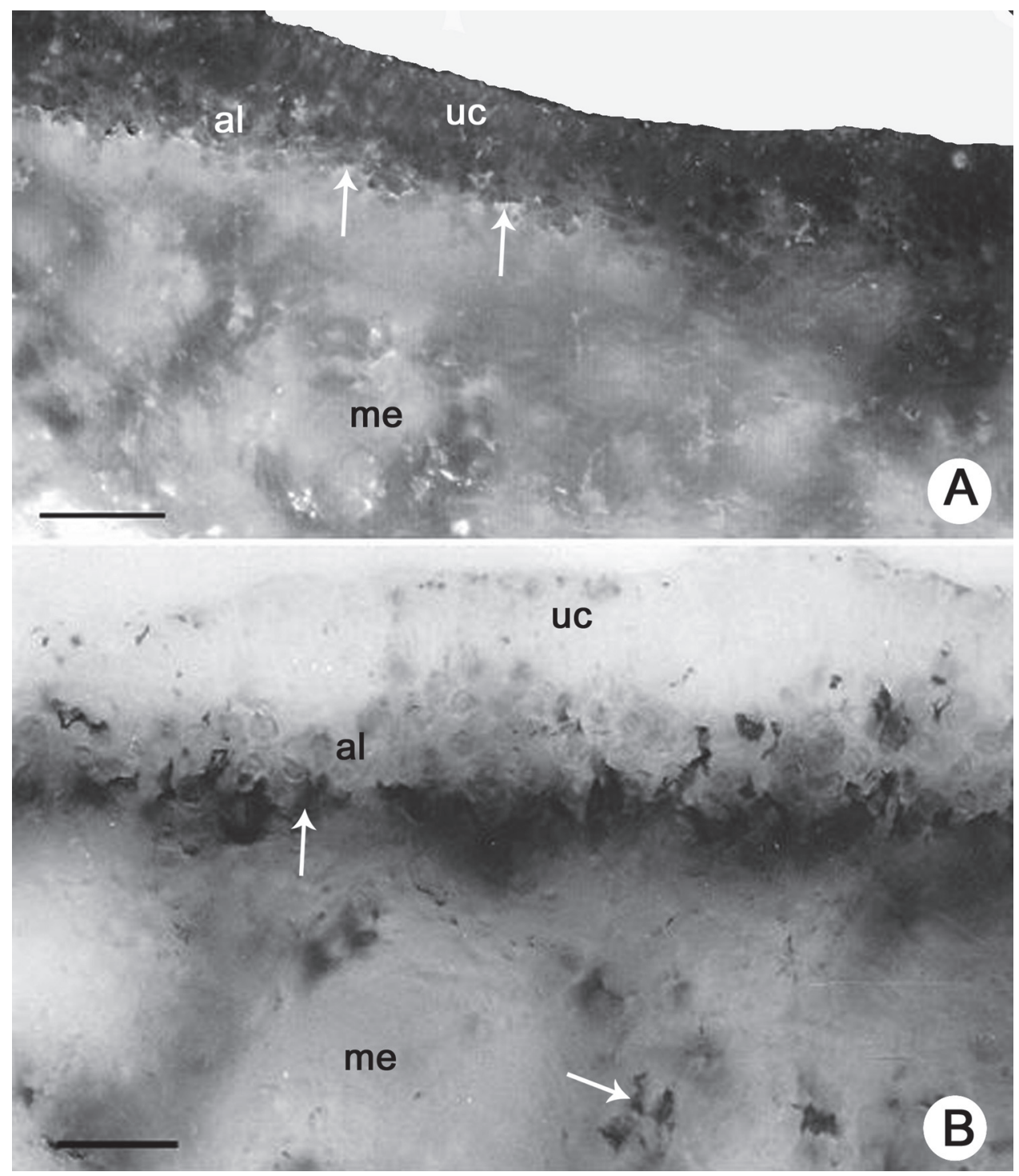

Figure 3. Details of the upper region of Parmotrema cetratum (Ach.) Hale thallus - freehand sections of fresh material. (A). Under normal light. (B). Under polarized light. Upper cortex (uc), algal layer (al), medulla (me). Arrows indicate crystals of lichen acid forming a continuous stratum mainly in the region of contact with the algal layer. Bars $=100 \mu \mathrm{m}(\mathrm{A}), 50 \mu \mathrm{m}(\mathrm{B})$

Thallus differentiation - In the specimens studied the marginal rim is characterized by small cells of mycobiont densely compact, in division and not differentiated, thus making it impossible to differentiate between upper and lower cortex; mycobiont cells are accompanied by photobiont cells, and this region is characterized by mycobiont and photobiont cells in high division rates and are considered as a meristematic region (pseudomeristem sensu Honneger 1993) of lichen thallus, responsible for the thallus growth.

Following the upper region of the thallus, soon after the marginal region, begins the elongation region of the thallus, which corresponds to the young thallus region. This region is stratified and composed of upper cortex, algal layer, medulla and lower cortex. The upper cortex is composed of larger, elongated cells forming a palisade prosoplectenchymatous tissue where a decreasing rate of cell division in the algal layer occurs, which correlates with an increasing in cell diameter.

The region of fully differentiated thallus, corresponding to the most central area of the thallus, is characterized by thicker upper cortex; it is the senescent part of the thallus, with the presence of dead cells from both mycobiont and photobiont.

The difference between the young and most development region of the thallus refers mainly to cortex thickness.

\section{Discussion}

The pattern of internal thalline development is similar in all specimens studied and is in agreement with Honegger (1993, 2008).

The data show that the two species are anatomically similar, including the anatomy of the upper cortex and characteristics of rhizines and cilia. 


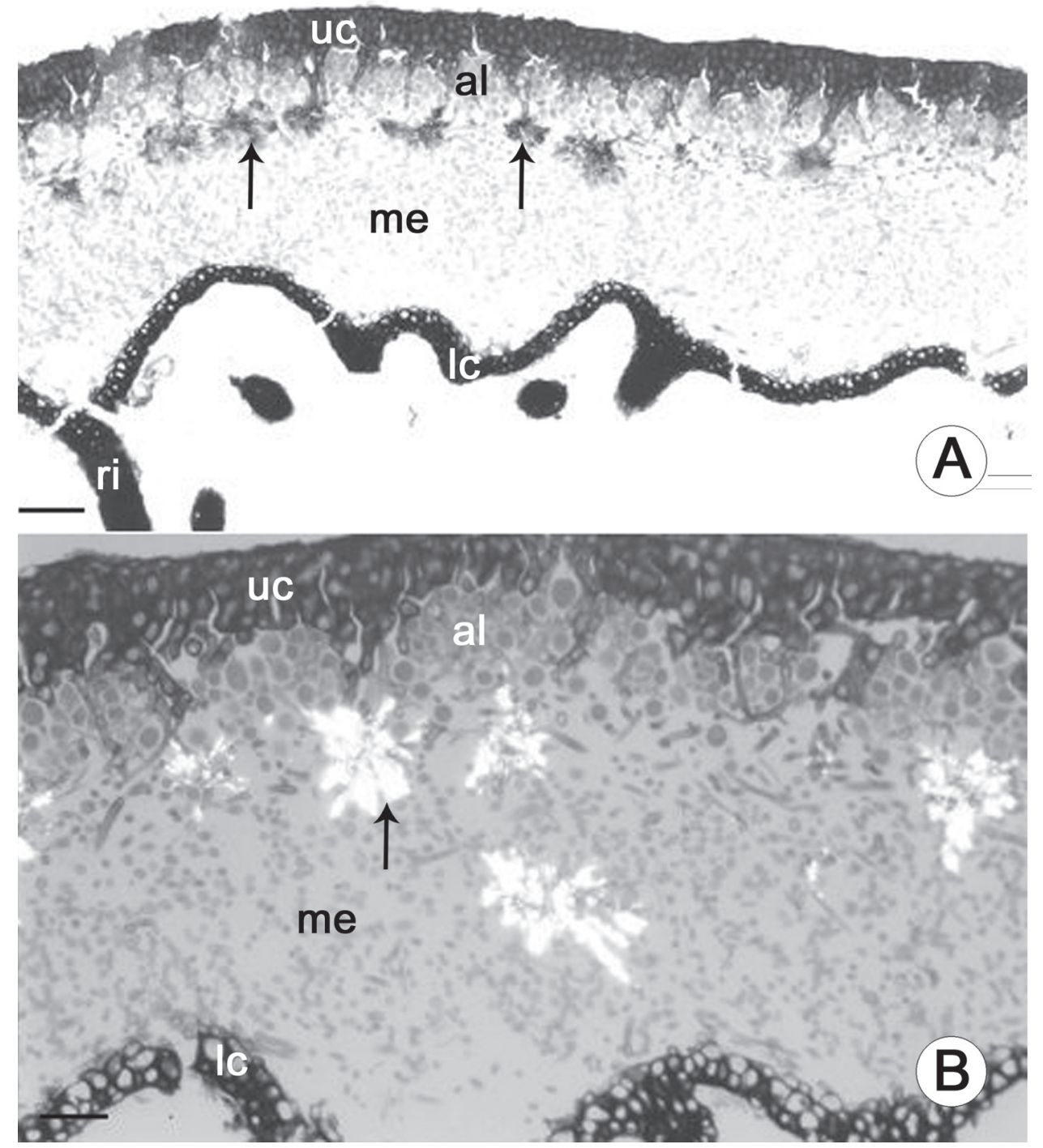

Figure 4. Thallus anatomy of Parmotrema cetratum (Ach.) Hale: presence and distribution of lichen acid crystals. (A). Transverse section visualized under normal light. (B). Transverse section visualized under polarized light. Crystals of lichen acids (arrows) forming an evident stratum and appearing as a row in the region of contact between the medulla and the algal layer, crystals concentrate in star-shaped hyphal agglomerates; upper cortex (uc), algal layer (al), medulla (me), lower cortex (lc) and rhizine (ri). Bars $=100 \mu \mathrm{m}$.

In both species it was possible to visualize the epicortex (Fig. 1A, 2A, 2B) which, despite being regarded as a thin layer of polysaccharides visible only in scanning electron microscopy (Hale 1973), was easily visualized using a light microscope in several studies (Barbosa et al. 2009a/b).

The upper cortex is palisade prosoplectenchymatous, characterized by slightly elongated cells with thickened cell wall and presenting macules that may cause cracks, responsible for the reticulated maculated patter of the thallus, agreeing with that considered by several authors (Benatti \& Marcelli 2008; Elix 1993; Hale \& Fletcher 1990) (Fig. 1A, 1B, 2A, 2B).

The macules have been described as white patches (or colored in the case of spcies with colored medulla) resulting from the simple absence of algae in certain parts of the algal layer (Marcelli 2006). However, the formation and anatomical structure of maculae, described here for the first time, is much more complex than the simple absence of algae. Anatomically, they are a consequence of the ramification of hyphae leaving the medulla to form the upper cortex in palisade. Crossing the algal layer, the hyphae that organize the cortex furcate as a plume, but remain aggregated in compact bundles, that al the algal layer level, separating the photobiont cells into groups (Fig. 1A, 2A). In this way, the spaces between the groups of algal cells, occupied by hyphae of the fungus, morphologically appear as macules on the surface of the thallus, that, rather than reveal no photobiont, indicate patterns of organization of generating hyphae of upper cortex. As the pattern of macules has been used in the characterization of genera and species in many groups of lichenized fungi, the fact that they lead the way to structuralize the cortex is highly significant and worthy 

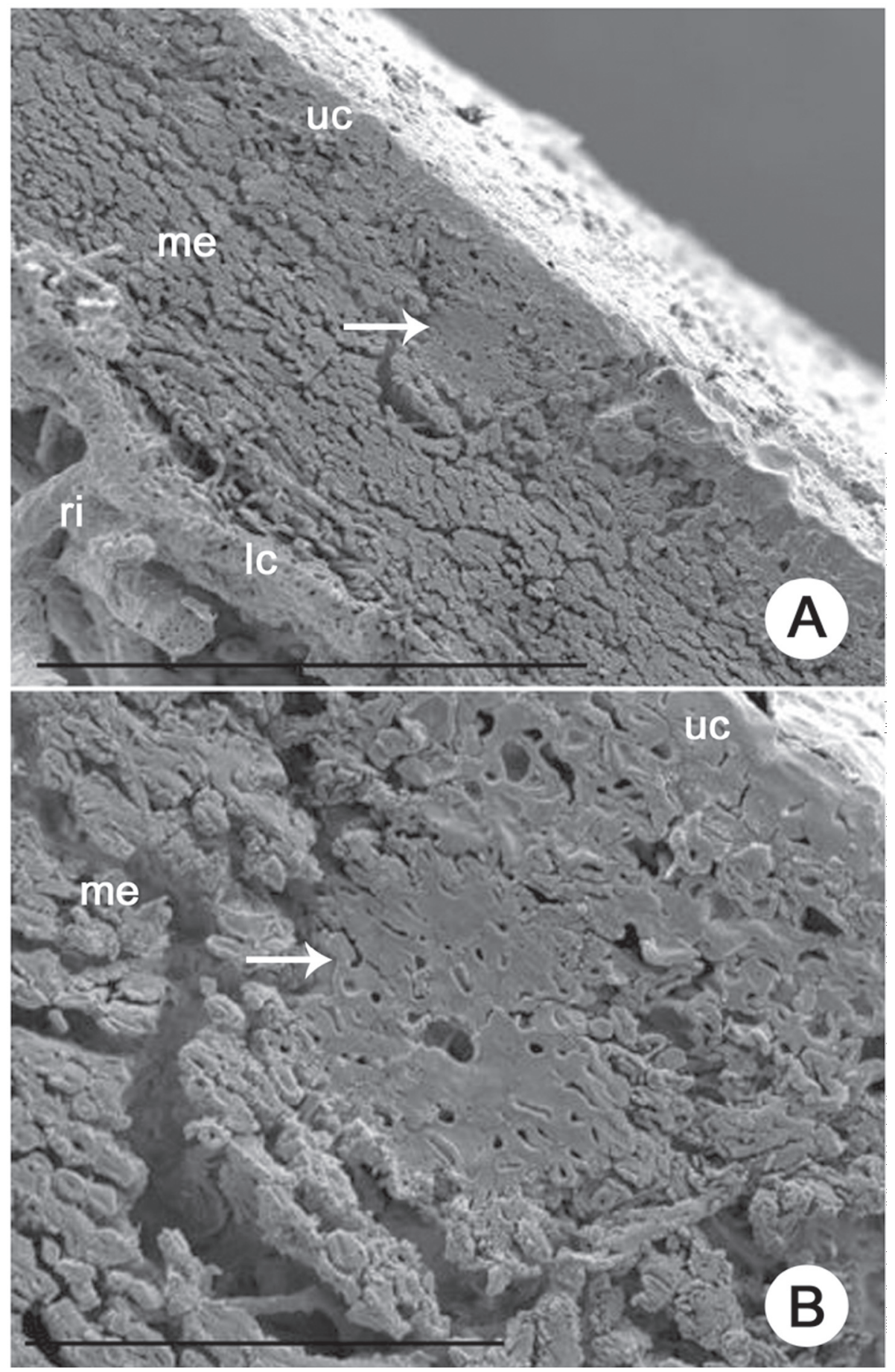

Figure 5. Transverse sections of Parmotrema cetratum thallus visualized under scanning electron microscope, indicating the upper cortex (uc), medulla (me) with star-shaped hyphal agglomerate (arrow), lower cortex (lc) and rhizines (ri). Bars $=200 \mu \mathrm{m}$ (A), $50 \mu \mathrm{m}$ (B).

of greater attention in the future. Whether the formation and structure of the macules are the same in other taxonomic groups is still subject to further studies.

Moreover, the regular crack features of the group of species studied are originated precisely in the place of formation of macules and anatomically show up as spaces separating small bouquets of hyphae organizing the upper cortex, thus avoiding exposure of the algal cells, but assured the proper aeration of the thallus, which has a dense, thick upper cortex (Fig. 2A).

The upper cortex anatomy is considered a valid taxonomic character in many lichen groups and used for delimitation of families like Pyxinaceae [Physciaceae] (Moberg 1977) and Ramalinaceae (Bowler 1981) and distinction of genera such as Bryocaulon, Coelocaulon and Cornicularia (Kärnefelt 1986), Parmelia and Punctelia (Modenesi 1987). 
This study indicates that there is a pattern in the structure of upper cortex in species of Parmotrema with upper surface reticulate maculate, and this pattern can be used for placing these species within a single group within the genus Parmotrema. We have observed in recent years that in species of different genera in Parmeliaceae the arrangement of cortical cells is quite distinct from that observed in these particular species of Parmotrema. For example, in Punctelia (Barbosa 2009) the upper cortex is characterized by having more or less isodiametric cells that form a well compacted paraplectenchymatous tissue, besides the presence of pseudocyphelae, characteristic of the genera. In Parmelinopsis minarum (Vainio) Elix \& Hale the cells of the upper cortex do not form a continuos arrangement (Barbosa et al. 2009b); in Canoparmelia texana (Tuck.) Elix $\&$ Hale the upper cortex is characterized by the presence of large gaps between cells (Barbosa 2004), and in Parmotrema tinctorum the upper cortex is very thick and hyphal cells are agglutinated, but there are small interstices which may work together with epicortical pores in gas exchanges (Barbosa et al. 2009b).

The upper cortex organization in both species also seems to be associated with thallus water uptake and $\mathrm{CO}_{2}$ diffusion capacity, as pointed out by several authors (Hale 1981; Elix 1993; Tretiach et al. 2005; Crespo et al. 2006; Barbosa et al. 2009b). High cortex thickness may work as a barrier to water diffusion, lengthening thallus saturation time, as observed by Hale (1981) in other Parmeliaceae species.

In the medulla of the Parmotrema species studied there are star-shaped hyphal agglomerates just below the algal layer and in association with the hyphae leaving the medulla and through the algal layer to form the upper cortex. Furthermore, these hyphae are covered with crystals, revealed with the aid of a microscope with polarized light (Fig. 1B, 2D). Due to its characteristic shape, the possibility that these clusters are artifacts of technique or were from the dissolution and recrystallization of lichen acids is suggested, but the controls were clear in showing that in fact these are natural clusters in the medulla of these species (Fig. 3A, $3 \mathrm{~B}, 4 \mathrm{~A}, 4 \mathrm{~B}, 5 \mathrm{~A}, 5 \mathrm{~B})$. The presence of these clusters should be associated with the presence of salazinic acid, which occurs simultaneously in the medulla of these two species of Parmotrema. There is no previous report in the literature about the presence of clusters associated with salazinc acid.

Medullary hyphae serve as reserve tissue, accumulating substances for subsequent utilization (Schneider 1897). Lichens may store these metabolic products for future use before they are remobilized. In the medulla of $P$. cetratum and $P$. clavuliferum crystals of lichen acids appeared as a stratum immediately below the algal layer and in close association with hyphae that grow from the medulla through the algal layer to form the upper cortex, indicating a metabolic relationship between the medullar crystals and the cortex. Such impermeable incrustations of lichen substances next to the algal layer may assist in maintaining air bubbles in thalli saturated with water or increase the algal cell wall permeability and facilitate carbohydrate exchange between the alga and the fungi (Rundel 1978). Substances such as salazinic acid may also exhibit allelopathic and antibiotic activity, protecting the thallus against herbivores, fungi and pathogenic bacteria. These are essential functions since lichens have significant longevity and suffer frequent saturation (Rundel 1978).

However there are differences between species, related to the thickness of medulla and the pattern of organization and orientation of medullary hyphae. The medulla of $P$. cetratum is almost twice the thickness of the medulla of P. clavuliferum. In P. cetratum the medullary hyphae are predominantly horizontal longitudinal and P. clavuliferum the medullary hyphae are arranged in three layers.

Both species have prosoplectenchymatous lower cortex and corticated rhizines (Fig. 1C, 2C). The presence of a cortex layer covering hyphae of rhizines may be related to the need for a mechanical tissue to assist in support of the thallus that, in the species studied, is large and poorly adhered to the substrate, as seen by Barbosa et al. (2009b) for Parmotrema tinctorum.

\section{Acknowledgements}

We thank S.R. Machado for the assistance provided during the development of this work, CAPES for the fellowship to S. B. Barbosa, $\mathrm{CNPq}$ research grant to M. P. Marcelli and the technical team of the Institute of Biosciences' Electron Microscopy Center, UNESP Botucatu, SP, Brasil, for their helpful technical advice.

\section{References}

Barbosa, S.B. 2004. Estudos anatômicos em quatro espécies de Parmeliaceae (Ascomycota liquenizados). Master Thesis in Biological Sciences (Botany). São Paulo State University, UNESP, Botucatu, Sao Paulo State, Brasil.

Barbosa, S.B. 2009. Aplicabilidade taxonômica de variações anatômicas em fungos liquenizados. Thesis in Biological Sciences (Botany). São Paulo State University, UNESP, Botucatu, Sao Paulo State, Brasil.

Barbosa, S.B.; Marcelli, M.P. \& Machado, S.R. 2009a. Evaluation of different protocols for anatomical studies in Parmeliaceae (lichenized Ascomycota). Micron 40: 218-225.

Barbosa, S.B.; Machado, S.R. \& Marcelli, M.P. 2009b. Thallus structure and isidium development in two Parmeliaceae species (lichenized Ascomycota). Micron 40: 536-542.

Benatti, M.N. \& Marcelli, M.P. 2008. Espécies de Parmotrema (Parmeliaceae, Ascomycetes liquenizados) com máculas reticulares do litoral centro-sul do Estado de São Paulo, Brasil. Hoehnea 35: 75-90.

Blanco, O.; Crespo, A.; Divakar, P.K.; Esslinger, T.L.; Hawksworth, D.L. \& Lumbsch, T.H. 2004a. Melanelixia and Melanohalea, two new genera segregated from Melanelia (Parmeliaceae) based on molecular and morphological data. Mycological Research 108: 873-884.

Blanco, O.; Crespo, A.; Elix, J.A.; Hawksworth, D.L. \& Lumbsch, H.T. 2004b. A molecular pylogeny and a new classification of parmelioid lichens containing Xanthoparmelia-type lichenan (Ascomycota: Lecanorales). Taxon 55: 959-975.

Blanco, O.; Crespo, A.; Divakar, P.K.; Elix, J.A. \& Lumbsh, H.T. (2005): Molecular phylogeny of parmotremoid lichens (Ascomycota, Parmeliaceae). Mycologia 97: 150-159. 
Bowler, P.A. 1981. Cortical diversity in the Ramalinaceae. Canadian Journal of Botany 59: 425-557.

Crespo, A.; Arguello, A.; Blanco, O.; Gasca, C. \& Molina, M.C. 2006. Sistemática e valor dos caracteres em liquens. Pp. 471-502. In: Xavier Filho, L.; Legaz, M.E.; Cordoba, C.V. \& Pereira, E.C. (eds.): Biologia de Liquens. Rio de Janeiro, Âmbito Cultural Edições Ltda.

Crespo, A.; Lumbsh, T.; Mattsson, J.E.; Blanco, O.; Divakar, P.K.; Articus, K.; Wiklund, E.; Bawingan, P.A. \& Wedin, M. (2007): Testing morphology-based hypotheses of phylogenetic relationships in Parmeliaceae (Ascomycota) using three ribosomal markers and nuclear RPB1 gene. Molecular Phylogenetics and Evolution 44: 812-824.

Divakar, P.K.; Crespo, A.; Blanco, O. \& Lumbsh, T.H. 2006. Phylogenetic significance of morphological characters in the tropical Hypotrachyna clade of parmelioid lichens (Parmeliaceae, Ascomycota). Molecular Phylogenetics and Evolution 40: 448-458.

Elix, J.A. 1993. Progress in the generic delimitation of Parmelia sensu lato lichens (Ascomycotina: Parmeliaceae) and a synoptic key to the Parmeliaceae. The Bryologist 96: 359-383.

Elix, J.A. 1997. The lichen genera Canomaculina and Rimeliella (Ascomycotina, Parmeliaceae). Mycotaxon 65: 475-479.

Elix, J.A. 2003. The lichen genus Paraparmelia, a synonym of Xanthoparmelia (Ascomycota, Parmeliaceae). Mycotaxon 87: 395 403.

Hale, M.E. 1973. Fine structure of the cortex in the lichen family Parmeliaceae viewed with a scanning electron microscope. Smithsonian Contributions to Botany 10: 1-92.

Hale, M.E. 1974. New combinations in the lichen genus Parmotrema Massalongo. Phytologia 28(4): 334-339.

Hale, M.E. 1976. Lichen structure viewed with the scanning electron microscope. Pp. 1-15. In: Brown, D.H.; Hawksworth, D.L. \& Bailey, B.H. (eds.): Lichenology: Progress and Problems. Academic Press, London.
Hale, M.E. 1981. Pseudocyphellae and pored epicortex in the Parmeliaceae: their delimitation and evolutionary significance. Lichenologist 13: 1-10.

Hale, M.E. \& Fletcher, A. 1990. Rimelia Hale \& Fletcher, a new lichen genus (Ascomycotina: Parmeliaceae). The Bryologist 93: 121-191.

Hawksworth, D.L. \& Crespo, A. 2002. Proposal to conserve the name Xanthoparmelia against Chondropsis nom. cons. (Parmeliaceae). Taxon 51: 807-807.

Honegger, R. 1993. Developmental biology of lichens. New Phytologyst 125: $659-677$

Honegger, R. 2008. Morphogenesis. Pp. 69-93. In: Nash, T.H. III (ed.). Lichen biology 2 nd ed. Cambridge, Cambridge University Press.

Johansen, D.A. 1940. Plant microtechnique. New York, Mc Graw-Hill.

Kärnefelt, I. 1986. The genera Bryocaulon, Coelocaulon and Cornicularia and formely associated taxa. Opera Botanica 86: 1-90.

Marcelli, M.P. 2006. Fungos Liquenizados. Pp. 503-520. In: Xavier Filho, L.; Legaz, M.E.; Cordoba, C.V. \& Pereira, E.C. (eds.). Biologia de Liquens. Âmbito Cultural Edições Ltda., Rio de Janeiro.

Moberg, R. 1977. The lichen genus Physcia and allied genera in Fennoscandia. Symbolae Botanicae Upsalienses 22: 1-108.

Modenesi, P. 1987. Histochemistry and generic delimitation in Parmelia and Punctelia. Nova Hedwigia 45: 423-431.

O’Brien, T.P., Feder, N., McCully, M.E. 1965. Polychromatic staining of plant cell walls by toluidine blue O. Protoplasma 63: 443-478.

Rundel, P.W. 1978. The ecological role of secondary lichen substances. Biochemical Systematics and Ecology 6: 157-170.

Schneider, A. 1897. A text-book of general lichenology. Willard N. Clute \& Co, New York.

Streimann, H. 1986. Catalogue of the lichens of Papua New Guinea and Irian Jaya. Bibliotheca Lichenologica 22: 154p.

Tretiach, M., Crisafulli, P., Pittao, E., Rinino, S., Roccotiello, E., Modenesi, P. 2005. Isidia ontogeny and its effect on the CO2 gas exchanges of the epiphytic lichen Pseudevernia furfuracea (1.) Zopft. The Lichenologist 37(5): 445-462. 